\title{
MELATIH SISWA MELAKUKAN ANALISIS \\ DALAM PEMBELAJARAN SEJARAH MELALUI MODEL INDUKTIF KATA BERGAMBAR
}

\author{
Raihani Sawitri \\ Program Studi Pendidikan Sejarah FKIP Universitas Lambung Mangkurat \\ Banjarmasin \\ Email: raihanisawitri400@gmail.com
}

\begin{abstract}
Abstak: Pembelajaran Sejarah dengan menggunakan model Induktif kata bergambar bisa memberikan warna baru terhadap pembelajaran sejarah. Model induktif kata bergambar memberikan kesempatan kepada siswa untuk aktif mengamati gambar yang ditampilkan dan melakukan analisis serta membuat paragraf ilmiah tapi, dengan latar belakang dengan materi pembelajaran Sejarah. Aktivitas mengamati gambar, menuliskan kata-kata, dan menganalisis menjadi pembelajaran yang bermakna karena membantu siswa dalam mengekspresikan pengalaman mereka. Hal ini akan melatih siswa melakukan analisis dan membuat paragraf Ilmiah dalam pembelajaran Sejarah melalui model Induktif kata bergambar.
\end{abstract}

Kata kunci: Kemampuan Menganalisis, Model Induktif Kata Bergambar

\section{PENDAHULUAN}

Banyak hal yang bisa dilakukan siswa dalam pembelajaran tidak hanya membaca dan mencatat peristiwa yang tedalam pembelajaran sejarah saja namun sebagai seorang guru sejarah bagaimana kita bisa menerapkan berbagai model pembelajaran yang memiliki banyak jenis dan fungsinya, sehingga membuat siswa ikut berperan aktif dalam kegiatan pemebelajan. Dalam pembelajaran, peserta didik harus dilibatkan dalam aktivitas menganalisis dan menemukan pola, didorong untuk mengemukakan argumen dan mendeskripsikan hubungan hubungan antarkonsep dan antargagasan. Saat anak mendemonstrasikan hubungan hubungan tersebut, maka pengetahuan yang diperoleh bisa digunakan untuk memecahkan persoalan baru. ${ }^{1}$ Kemampuan berpikir analisis adalah kemampuan berpikir siswa untuk menguraikan informasi-informasi yang digunakan untuk memahami suatu pengetahuan dengan menggunakan akal dan pikiran yang logis, bukan berdasar perasaan.Dengan menggunakan model Induktif kata bergambar peserta didik bisa menganalisis berdasarkan materi yang kita berikan sehingga menciptakan pengetahuan baru dan membuat paragrf sistematis.

\footnotetext{
${ }^{1}$ Ikhlasul Ardi Nugroho. Pendekatan Ilmiah Dalam Pembelajaran Lintas Kurikulum Di Sekolah Dasar. (Ikhlasul Workshop, 2016) Hlm. 80.
} 


\section{MELATIH SISWA MELAKUKAN ANALISIS DALAM PEMBELAJARAN SEJARAH}

Dalam dunia pendidikan guru memiliki peran penting dalam proses pembelajaran. Kemampuan guru dalam melaksanakan kegiatan mengajar meruapakan faktor penting untuk mencapai tujuan pendidikan. Secara umum guru bertugas mengembangkan kemampuan siswa secara optimal dalam aspek kognitif, afektif dan psikomotorik. Dalam menjalankan tugas dan tanggung jawabnya, seorang guru perlu menjadi pribadi yang mulia, memiliki sikap yang membaut para siswa merasa nyaman dengan memberikan pengajaran dengan untaian kata kata sarat yang bermakna mendidik. ${ }^{2}$ Pada proses pembelajaran diharapkan siswa belajar atau mendapatkan pelajaran dari guru, siswa tidak hanya mampu memahami teori dan mampu melakukan praktek, tetapi mampu juga untuk menggunakan keterampilan bahasanya baik secara lisan maupun tulisan untuk diaplikasikan dalam kehidupan sosial atau lingkungannya. Siswa juga harus mampu menggunakan keterampilan bahasanya dengan baik dalam pembelajaran. Keterampilan dalam menggunakan bahasa khususnya keterampilan berargumentasi merupakan kemampuan yang memegang peranan penting dalam kehidupan sosial, maka sains pun tidak lepas dari kemampuan tersebut. ${ }^{3}$

Analisis adalah kemampuan menguraikan atau memecahkan suatu bahan pelajaran kedalam bagian bagian atau unsur unsur serta hubungan antar bagian bahan itu. Analisis merupakan tujuan pembelajaran yang kompleks yang di mana yang hanya mungkin dipahami dan dikuasi oleh siswa yang telah dapat menguasai kemampuan memahami dan menerapkan. Analisis berhubungan dengan kemampuan nalar. Oleh karena itu, biasanya analisis diperuntukan untuk pencapaian tujuan pemebelajaran untuk siswa siswa tinggkat atas. ${ }^{4}$

Pembelajaran Sejarah dengan melakukan analisis akan menghasilkan nalar atau pemikiran yang baru bagi siswa dengan adanya analisis yang dilakukan maka tanpa sadar peserta didik berpikir secara kritis sesuai dengan materi yang ditentukan. Sehingga, menghasilkan pengetahuan yang baru. Standar pembelajaran Sejarah memuat aktivitas menganalisis, membandingkan, mengeksplorasi, dan menjelaskan yang merupakan keterampilan utama dalam rangka menginterpretasi data data sejarah. Saat melakukan dalam kegiatan pembelajaran sejarah. Perlu adanya aplikasi keterampilan proses yang dibutuhkan

2 Melisa Prawitasari. METODE PEMBELAJARAN HYPOTEACHING MELALUI MIND MIPPING DALAM PEMBELAJARAN SEJARAH. Studi Pada Siswa Kelas XI IPS SMA PGRI 6 Banjarmasin). Program Studi Pendidikan Sejarah FKIP Unlam Banjarmasin. 2015).

${ }^{3}$ Sindy Dewina, dkk. PENGARUH MODEL PEMBELAJARAN PROBLEM BASED LEARNING (PBL) TERHADAP KEMAMPUAN MENGANALISIS DAN KETERAMPILAN BERARGUMENTASI SISWA PADA KONSEP PENCEMARAN LINGKUNGAN DI KELAS X. (Jurnal Pendidikan dan Biologi. 2017). hlm 48.

${ }^{4}$ Wina sanjaya, dan Andi Budimanjaya. Paradigma Baru Mengajar. (Jakarta; Kencana, 2017). hlm. 91. 
untuk menganalisis cerita cerita dan menjawab pertanyaan pertanyaan yang dapat diterjemahkan menjadi suatu data dari tempat dan wktu yang berbeda beda. ${ }^{5}$

\section{MODEL INDUKTIF KATA BERGAMBAR}

Model pembelajaran merupakan suatu perencanaan atau sutu pola yang digunakan sebagai pedoman dalam merencanakan pembelajaan didalam kelas. Model pembelajaran juga mengacu pada pendekatan pembelajaran yang digunakan, termaksuk didalamnya tujuan tujuan pengajaran, tahap tahap dalam kegiatan pemebelajaran dan pengelolaan kelas. ${ }^{6}$ Model pembelajaran juga merupakan suatu rancangan untuk tujuan tujuan tertentu dengan melibatkan peserta didik untuk aktif dalam tugas tugas kognitif dan sosial tertentu. Sebagian model berpusat pada penyampaian guru sementara sebagian yang lain berusaha berfokus pada respon peserta didik dalam mengerjakan tugas dan posisi posisi peserta didik sebagai patner dalam proses pembelajaran. ${ }^{7}$

Menurut Joyce dkk., (1992:1) dalam JurnalTomasouw, menegaskan bahwa model-model pengajaran pada dasarnya dapat membantu pembelajar untuk memperoleh informasi, gagasan, kompetensi, nilai, cara berpikir, dan untuk mengekspresikan diri mereka sendiri, kita sebenarnya sedang mengajari mereka untuk bagaimana belajar. Pada hakikatnya, hasil pengajaran jangka panjang yang paling penting adalah bagaimana siswa mampu meningkatkan belajarnya dengan lebih mudah dan lebih efektif pada masa yang akan datang.

Menurut Miftahul Huda, Dalam skripsi Basana Sari model Induktif kata Bergambar merupakan suatu rancangan untuk menghadapi tantangan untuk menjadi pembaca ahli, peserta didik harus didorong untuk banyak membaca, mengembangkan kosa kata, mengembangkan keterampilan dalam analisis Fenotik dan Struktural, dan belajar memahami memanfaatkan teks teks yang terhampar luas. ${ }^{8}$

Model pembelajaran induktif kata bergambar (Picture Word Inductif Model PWIM) menyajikan sebuah model pembelajaran yang memusatkan pada otak manusia untuk aktif berfikir melalui data-data yang diterimanya. Pengumpulan data-data yang bersifat kusus akan diproses dan ditarik kesimpulan secara umum. Secara tidak langsung siswa dilatih untuk mandiri dan konsisten terhadap permasalahan yang dihadapi dengan mengambil kesimpulan yang lebih obyetif dari data yang telah diproses. Model Induktif Kata Bergambar adalah penyelidikan berorientasi strategi seni bahasa yang menggunakan gambar yang

\footnotetext{
5 Ikhlasul Ardi Nugroho. Op. Cit Hlm. 77

6 Trianto, Model Pembelajaran Terpadu, ( Jakarta; Bumi Aksara, 2014 ). hlm 51-52.

7 Miftahul Huda, Model model Pengajaran dan Pembelajaran, (Pustaka Pelajar, 2015). hlm. 73

${ }^{8}$ Sari,Buana. PENERAPAN MODEL INDUKTIF KATA BERGAMBAR UNTUK MENINGKATKAN MINAT MEMBACA APADA MATA PELAJARAN BAHASA INDONESIA KELAS II MIN 3 KOTA MATARAM TAHUN PELAJARAN 2017/2018. (Univesitas Islam Negeri Mataram). hlm. 5.
} 
berisi benda benda asing dan tindakan untuk memperoleh kata-kata dari mendengarkan anak-anak dan berbicara kosakata.

Tujuan Picture Word Inductif Model (PWIM) adalah untuk:

1. Membangun pandangan kosakata sebagai dasar untuk membaca, belajar mengucapkan dan generalisasi ejaan

2. Memperoleh rasa percaya pada kemampuan seseorang untuk belajar

3. Belajar bagaimana menyelidiki bahasa dan menggunakan pengetahuan dan keterampilan untuk membaca, menulis dan berpartisipasi penuh dalam pendidikan. ${ }^{9}$

\section{PENERAPAN MODEL INDUKTIF KATA BERGAMBAR TERHADAP PEMBELAJARAN SEJARAH}

Model Induktif kata Bergambar sangat memungkinkan untuk diterapkan pada banyak materi pembelajaran sejarah. Kreativitas guru sangat diperlukan dalam penerapan model ini, terlebih karena model ini menggunakan kata dan gambar yang harus relevan dengan materi pembelajaran. Model ini pada awalnya Model ini pada awalnya hanya digunakan untuk melatih kemampuan bahasa anak pada tingkat dasar dengan menggunakan visualisasi dari tiap kata. Akan tetapi model ini juga sangat memungkinkan untuk diterapkan pada pembelajaran di tingkat yang lebih tinggi ${ }^{10}$

1. Guru menyajikan gambar (satu atau beberapa), tiap ga mbar dilengkapi dengan tema dan kata-kata yang menjadi petunjuk.

Aplikasi; pada materi "Pusat-pusat Perdagangan dan Kekuasaan serta Jalur Pelayaran di Nusantara Sebelum dan Setelah Kejatuhan Malaka” disajikan dua gambar sebagai berikut:

Peta 1. Pelayaran dan perdagangan sebelum kejatuhan Malaka

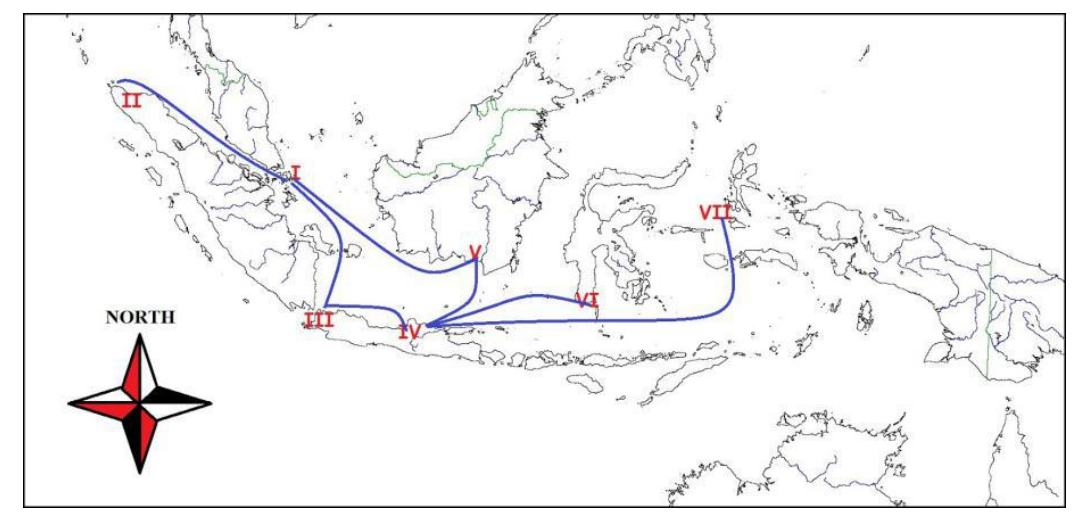

Kata petunjuk:

\footnotetext{
${ }^{9}$ Jolanda Tomasouw. mengembangkan kemampuan baca tulis bahasa jerman sebagai bahasa asing melalui model induktif kata bergambar. (Bali. 2013). hlm. 369.

10 Heri susanto, Seputar Pembelajaran Sejarah (isu, gagasan, dan stategi Pembelajara ):( Banjarmasin: Aswaja Pressindo, 2014 ), hlm. 102.
} 
I. Malaka II. Pasai III.Banten IV.Demak V.Banjar VI.Makassar VII.Ternate \& Tidore.

Peta 2. Pelayaran dan perdagangan setelah kejatuhan Malaka

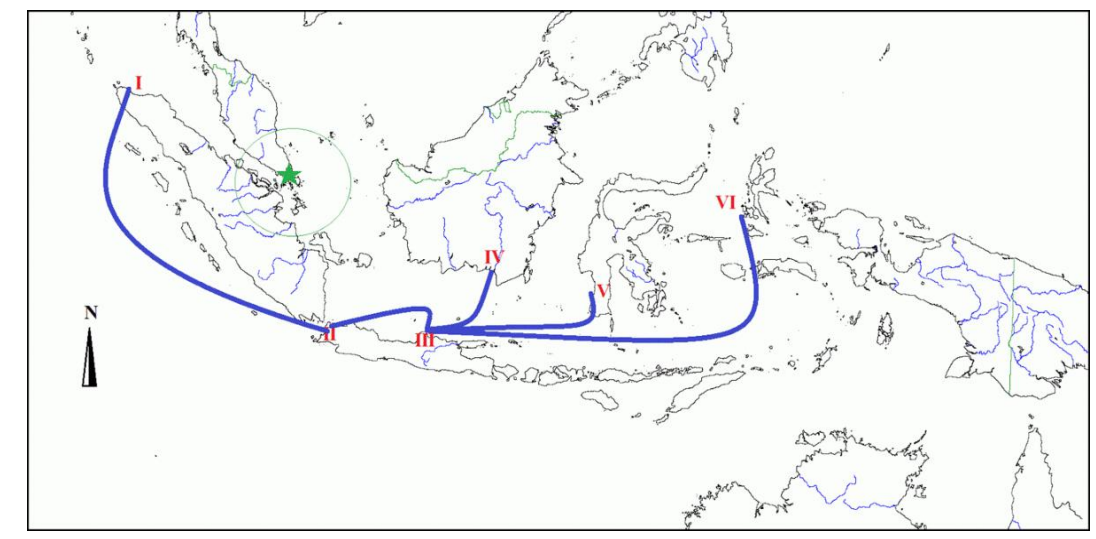

Kata petunjuk:

I. Pasai II. Banten III. Demak IV. Banjar V. Makassar VI. Ternate \& Tidore

2. Membangun generalisasi dengan menggunakan kosa kata.

Aplikasi; siswa diminta untuk mempelajari sejarah tiap daerah, kemudian membuat generalisasi dari tiap wilayah. Selanjutnya siswa diminta untuk membandingkan kedua gambar dan diminta untuk membuat generalisasi dari keduanya.

3. Deskripsi

Aplikasi; siswa diminta untuk membuat paragraf sistematis dengan berdasarkan pada analisa yang telah dibuat dan didukung oleh literatur yang tersedia. ${ }^{11}$

Dampak penerapan model induktif kata bergambar:

Menggunakan model pengajaran yang tepat akan memberikan dampak yang baik bagi melatih siswa melakukan analisis dan membuat paragraf ilmiah dalam pembelajaran sejarah melalui model induktif kata bergambar. Dalam model induktif kata bergambar, pembelajaran dapat dilakukan secara kelompok maupun individu. Anak diberikan gambar, kemudian menandai kata yang sesuai dengan gambar dan mengejanya. Anak membaca kata, kemudian menggolongkan kata. ${ }^{12}$

Banyak indikator yang berpengaruh antara lain lemahnya motivasi belajar, penguasaan kosa kata mereka sangat minim, maupun penggunnaan model ataupun strategi mengajar yang kurang baik. Oleh karena itu tentu saja dibutuhkan suatu model pengajaran yang bisa memotivasi pembelajar sehingga tujuan yang diharapkan dapat tercapai. Salah satu model pembelajaran yang dapat menjawab tantangan tersebut di atas adalah model induktif kata bergambar (picture word

11 Heri susanto. Op. Cit. Hlm. 100.

12 Ilonadewi, Rusmitahati, "PENGARUH MODEL INDUKTIF KATA BERGAMBAR TERHADAP KEMAMPUAN MEMBACA PERMULAAN PADA ANAK TUNARUNGU KELAS I DI SDLB-B KARYA MULIA II SURABAYA". (Universitas Negeri Surabaya Fakultas Ilmu Pendidikan Jurusan Pendidikan Luar Biasa, 2015). Hlm. 3 
inductive model) yang merupakan pengembangan dari model memproses informasi (information-processing model).

Model induktif kata bergambar ini adalah memadukan model berpikir induktif dengan model penemuan konsep. Tujuannya adalah agar pembelajar dapat belajar kata, kalimat, dan paragraf dari sebuah gambar. Model pengajaran ini dirasakan sangat baik karena dapat memotivasikan pembelajar melalui gambar-gambar yang menarik sehingga hal tersebut dapat membangun skemata mereka. ${ }^{13}$

Kelebihan model ini adalah menyampaikan materi menjadi tidak verbalis. ${ }^{14}$ Sehingga kemampuan dari peserta didk bisa terlihat dalam melakukan kegitan pembelajaran. Kelebihan model ini juga berdampak pada peserta didik dalam melakukan analisis gambar sehingga menciptakan hasil dari pengamatan tersebut sehingga peserta didik bisa membuat atau membentuk karakter mereka bisa membuat paragraf sistematis dalam materi pemebelajaran Sejarah.

\section{PENUTUP}

Menggunakan model pengajaran yang tepat akan memberikan dampak yang baik bagi melatih siswa melakukan analisis dan membuat paragraf ilmiah dalam pembelajaran sejarah melalui model induktif kata bergambar. Induktif kata bergambar bisa memberikan warna baru terhadap pembelajaran sejarah. Dalam model induktif kata bergambar, pembelajaran dapat dilakukan secara kelompok maupun individu. Model induktif kata bergambar ini adalah memadukan model berpikir induktif dengan model penemuan konsep. Kelebihan model ini juga berdampak pada peserta didik dalam melakukan analisis gambar sehingga menciptakan hasil dari pengamatan tersebut sehingga peserta didik bisa membuat atau membentuk karakter mereka bisa membuat paragraf sistematis dalam materi pemebelajaran Sejarah.

\section{DAFTAR PUSTAKA}

Huda, Miftahul. Model model Pengajaran dan Pembelajaran. Pustaka Pelajar 2015.

Nugroho,Ikhlasul Ardi. Pendekatan Ilmiah Dalam Pembelajaran Lintas Kurikulum Di Sekolah Dasar. Ikhlasul Workshop. 2016.

Susanto, Heri. Seputar Pembelajaran Sejarah: Isu, Gagasan dan Strategi Pembelajaran. Aswaja Pressindo. 2014.

Sanjaya,Wina dan Budimanjaya, Andi. Paradigma Baru Mengajar. Kencana. 2017.

\footnotetext{
13 Jolanda Tomasouw. mengembangkan kemampuan baca tulis bahasa jerman sebagai bahasa asing melalui model induktif kata bergambar. (Bali. 2013). hlm. 2

${ }^{14}$ Heri susanto. Log. Cit.
} 
Tomasouw, Jolanda. Mengembangkan Kemampuan Baca tulis bahasa Jerman sebagai Bahasa Asing melalui Model Induktif Kata Bergambar. Bali. 2013.

Terianto, Feri. Pembelajaran Terpadu Di Sekolah Dasar. Umsida Press. 2018.

Dewina, Sindy ;Suganda,Ondi; Widiantie,Rahma. "PENGARUH MODEL PEMBELAJARAN PROBLEM BASED LEARNING (PBL) TERHADAP KEMAMPUAN MENGANALISIS DAN KETERAMPILAN BERARGUMENTASI SISWA PADA KONSEP PENCEMARAN LINGKUNGAN DI KELAS X. Jurnal Pendidikan dan Biologi. 9. 2 (2017).

Rusmitahati, Ilonadewi. "PENGARUH MODEL INDUKTIF KATA BERGAMBAR TERHADAP KEMAMPUAN MEMBACA PERMULAAN PADA ANAK TUNARUNGU KELAS I DI SDLB-B KARYA MULIA II SURABAYA". Universitas Negeri Surabaya Fakultas Ilmu Pendidikan Jurusan Pendidikan Luar Biasa. 2015.

Sari, Buana. "PENERAPAN MODEL INDUKTIF KATA BERGAMBAR UNTUK MENINGKATKAN MINAT MEMBACA APADA MATA PELAJARAN BAHASA INDONESIA KELAS II MIN 3 KOTA MATARAM TAHUN PELAJARAN 2017/2018". Univesitas Islam Negeri Mataram. Jurusan Madrasah Ibtidayiah ( PGMI ). 2018.

Prawitasari, Melisa. "METODE PEMBELAJARAN HYPOTEACHING MELALUI MIND MIPPING DALAM PEMBELAJARAN SEJARAH (Studi Pada Siswa Kelas XI IPS SMA PGRI 6 Banjarmasin)”. Program Studi Pendidikan Sejarah FKIP Unlam Banjarmasin. 2015. 